\title{
Expression of the Macrophage Colony-stimulating Factor and c-fms Genes in Human Acute Myeloblastic Leukemia Cells
}

\author{
Alessandro Rambaldi, Nabutaka Wakamiya, Edo Vellenga, Junko Horiguchi, \\ M. Kim Warren, Donald Kufe, and James D. Griffin \\ Divisions of Tumor Immunology and Laboratory of Clinical Pharmacology, Dana-Farber Cancer Institute, Boston, Massachusetts \\ 02115; Department of Cell Biology, Cetus Corporation, Emeryville, California 94608
}

\begin{abstract}
Macrophage colony-stimulating factor (CSF-1; M-CSF) is a growth factor required for growth and differentiation of mononuclear phagocytes. The effects of CSF-1 are mediated through binding to specific, high-affinity surface receptors encoded by the $c$-fms gene. CSF-1 and $c$-fms gene expression was investigated in fresh human acute myeloblastic leukemic cells by Northern blot hybridization using cDNA probes. $4.0-\mathrm{kb}$ CSF-1 transcripts were detected in 10 of 17 cases of acute myeloblastic leukemia (AML), while $c$-fms transcripts were detected in 7 of 15. Coexpression of CSF-1 and c-fms was observed in five cases, and in five other cases neither gene was expressed. In situ hybridization demonstrated that transcripts for CSF-1 were present in 70-90\% of cells in each of three cases studied while $c$-fms mRNA was detected in $40-70 \%$ of cells. The constitutive expression of CSF-1 transcripts was associated with production of CSF-1 protein, although detectable amounts of CSF-1 were not secreted unless the cells were exposed to phorbol ester. These results demonstrate that leukemic myeloblasts from a subset of patients with AML express transcripts for both the CSF-1 and CSF-1 receptor genes, often in the same leukemic cells in vitro.
\end{abstract}

\section{Introduction}

Acute myeloblastic leukemia (AML) ${ }^{1}$ is a highly lethal neoplasm characterized by excessive proliferation and aberrant differentiation of immature myeloid cells. Like normal hematopoietic progenitor cells, proliferation of AML cells in vitro can be stimulated in most cases by one or more of the hematopoietic growth factors known as colony stimulating factors (CSFs) (1). In the normal marrow, certain accessory cells (fibroblasts, endothelial cells, $\mathrm{T}$ lymphocytes, and monocytes) seem to be the major sources of CSFs (2), but there is evidence that certain retrovirus-induced murine and avian myeloid leukemic cells have acquired the ability to produce their own

Address correspondence and reprint requests to Dr. Donald W. Kufe, Laboratory of Clinical Pharmacology, Dana-Farber Cancer Institute, 44 Binney Street, Boston, MA 02115.

Received for publication 27 May 1987 and in revised form 28 September 1987.

1. Abbreviations used in this paper: AML, acute myeloblastic leukemia; CSF, colony-stimulating factor; FBS, fetal bovine serum; PMA, phorbol myristic acid.

J. Clin. Invest.

(C) The American Society for Clinical Investigation, Inc. 0021-9738/88/04/1030/06 \$2.00

Volume 81, April 1988, 1030-1035
CSFs $(2,3)$. For example, monocyte-macrophage tumors induced in vivo by a mouse $c-m y c$ retrovirus secrete (and respond to) CSF-1 as a secondary transforming event (4). Production of CSFs by human myeloid tumors has not been extensively investigated. Although we have previously demonstrated that $c$-fms RNA is expressed in populations of leukemic blasts (5), the present study was undertaken to investigate expression of both the CSF-1 and $c$-fms genes in AML. CSF-1 is normally required for the growth and differentiation of mononuclear phagocytes (6), while $c$-fms apparently codes for the CSF-1 receptor (a 165-kD glycoprotein with tyrosine kinase activity) (7).

\section{Methods}

Leukemic cells. Bone marrow or blood samples were obtained at diagnosis from 17 adult patients with AML. Mononuclear cells were isolated by sedimentation on Ficoll-Hypaque density gradients and samples were cryopreserved in liquid nitrogen until use. After thawing, leukemic cells were depleted of $\mathrm{T}$ cells by rosetting with sheep erythrocytes and depleted of monocytes by plastic adherence for $1 \mathrm{~h}$ at $37^{\circ} \mathrm{C}$. Specimens selected for study were shown to contain $>95 \%$ blasts. Cases were classified by French-American-British classification (8) and further characterized by determining expression of the CD14 monocyte surface antigen recognized by MAb anti-MY4 (9). In some experiments leukemic cells were cultured in RPMI 1640 medium containing $10 \%$ fetal bovine serum (FBS) and $10^{-10} \mathrm{M}$ phorbol myristate acetate (Sigma Chemical Co., St. Louis, MO) for $48 \mathrm{~h}$.

Normal cells. Blood monocytes were isolated from platelet pheresis residue packs by Ficoll-Hypaque density gradient sedimentation, Erosetting, and plastic adherence as previously described (9). Purity of monocyte preparations was monitored by immunofluorescence staining with anti-MY4 (9) and exceeded $95 \%$ for all experiments reported here. For some experiments, monocytes were cultured in RPMI 1640 medium containing $10 \%$ FBS and $1,000 \mathrm{U} / \mathrm{ml}$ recombinant, purified human gamma-interferon (Biogen, Cambridge, MA) for $18 \mathrm{~h}$.

CSF-1 assays. CSF activity in medium conditioned by leukemic cells $\left(1 \times 10^{6}\right.$ cells $/ \mathrm{ml}$ in RPMI 1640 with $10 \%$ fetal bovine serum for $48 \mathrm{~h}$ ) was measured by both colony assay and RIA. Normal murine marrow granulocyte monocyte progenitor cells (CFU-GM) were assayed in a standard double layer agar system in which $5 \times 10^{4}$ marrow cells were cultured in $0.3 \%$ agar and $20 \%$ FBS in Iscove's modified Dulbecco's minimal essential medium $(0.5 \mathrm{ml})$ over an underlayer containing $0.5 \%$ agar in the same medium $(0.5 \mathrm{ml})(9)$. Macrophage colonies were counted on day 7 in triplicate samples. The RIA was performed as previously described (10).

Northern blots. $50-100 \times 10^{6}$ leukemic blasts were lysed in $4 \mathrm{M}$ guanidium isothiocyanate and the RNA recovered after centrifugation through $5.7 \mathrm{M}$ cesium chloride as previously described (11). 15- $\mu \mathrm{g}$ samples of total cellular RNA were fractionated on $1.2 \%$ agarose gels containing $6 \%$ formaldehyde. All gels were stained with ethidium bromide to visualize $28 \mathrm{~S}$ and $18 \mathrm{~S}$ ribosomal RNA bands. These bands were used to confirm that approximately equivalent amounts of RNA were loaded in each gel lane, and that there was no obvious degradation of RNA. RNA was transferred to a synthetic nylon transfer mem- 

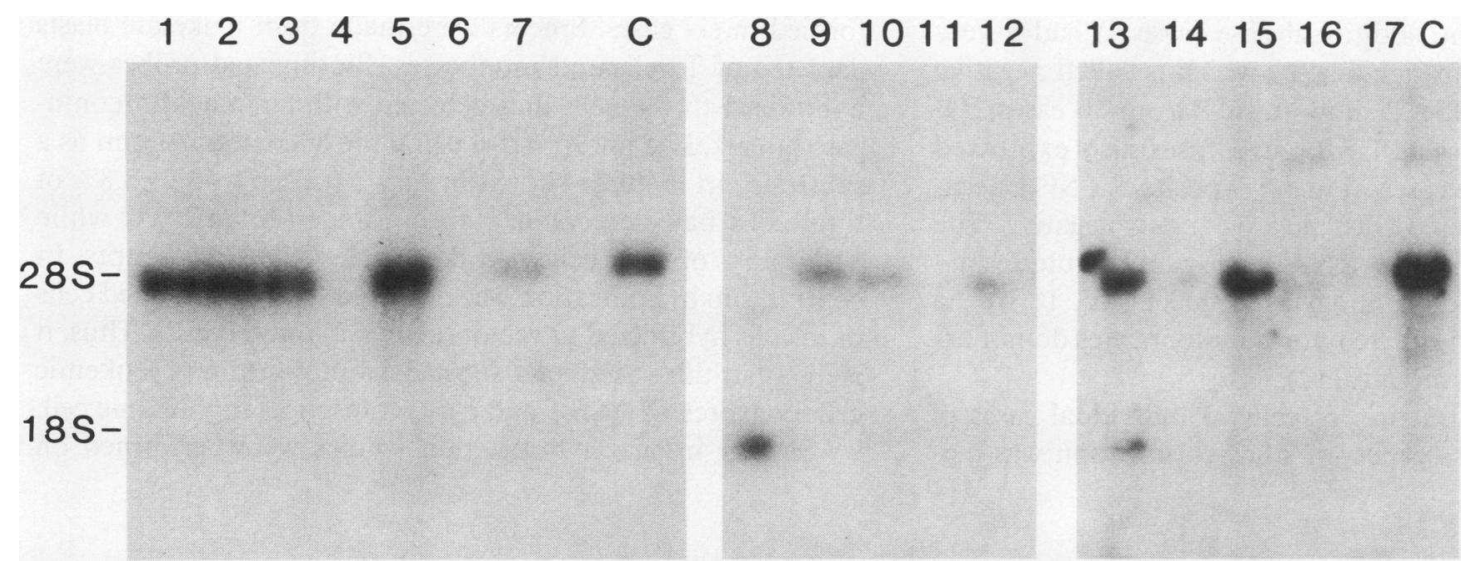

Figure 1. Expression of the CSF-1 gene by AML cells. Total cellular RNA (15 $\mu \mathrm{g})$ was fractionated on $1.2 \%$ agarose gels. CSF-1 mRNA was detected using a 3.5-kb segment of the human CSF-1 cDNA inserted in the Xho site of the pXMT 2 vector (13). The control lanes $(C)$ show RNA from gamma-interferon-stimulated normal blood monocytes. Unstimulated normal monocytes lack detectable CSF-1 RNA (21-23).

brane (GeneScreen Plus, E. I. Dupont de Nemours \& Co. Inc., Wilmington, DE), and prehybridized as previously described (11). CSF-1 mRNA was detected using a 3.5-kb segment of the human CSF-1 cDNA inserted in the Xho site of the pXMT 2 vector, provided by Drs. Gordon Wong and Steven Clark, Genetics Institute, Cambridge, MA. $c$-fms mRNA was detected with the pSM3 plasmid containing the 1.0-kb PstI fragment of $v$-fms. Probes were labeled using hexanucleotide primers and ${ }^{32} \mathrm{P}-\mathrm{dCTP}$ to specific activities of $10^{9} \mathrm{cpm} / \mu \mathrm{g}$. Hybridization was performed at $60^{\circ} \mathrm{C}$ as previously described (11). In situ hybridization was performed by nick-translating the same cDNA

Table I. Expression of CSF-1 and c-fms Genes by AML Cells

\begin{tabular}{rlrccc}
\hline & & & \multicolumn{2}{c}{ mRNA $^{8}$} \\
\cline { 4 - 5 } Case No. & FAB $^{*}$ & \%MY4+ & CSF-1 & c-fms \\
\hline 1 & M1 & 5 & ++ & + \\
2 & M1 & 1 & ++ & - \\
3 & M5b & NT" & ++ & NT \\
4 & M5 & 5 & - & \pm \\
5 & M4 & 30 & ++ & ++ \\
6 & M4 & NT & - & ++ \\
7 & M4 & NT & + & NT \\
8 & M1 & 0 & - & - \\
9 & M2 & 2 & + & + \\
10 & M1 & NT & + & + \\
11 & M2 & 26 & - & + \\
12 & M5b & 49 & + & + \\
13 & M5a & NT & ++ & - \\
14 & UNC. & NT & - & - \\
15 & M1 & 1 & ++ & - \\
16 & M2 & 3 & - & - \\
17 & M4 & 33 & - & - \\
& & & &
\end{tabular}

\footnotetext{
* French-American-British classification (7). UNC, unclassified.

¥ Surface binding of the CD14 anti-monocyte monoclonal antibody MY4 was detected by indirect immunofluorescence and flow cytometry.

${ }^{8}$ Data from Figs. 1 and $2 .-$, no detectable signal; + , detectable but less intense signal for $16 \mathrm{~h}$ exposure; ++ , intense signal for $16 \mathrm{~h}$ exposure.

"NT, not tested.
}

probes using biotinylated dUTP (Bethesda Research Laboratories, Gaithersburg, MD). The hybridization protocol was as previously described (12).

\section{Results}

Light-density leukemic cells were prepared from 17 newly diagnosed adult patients with AML (Table I). Samples contained $>90 \%$ blasts and were depleted of adherent cells and $T$ lymphocytes. A Northern blot analysis of total cellular RNA was performed with a CSF-1 cDNA probe previously shown to encode the $61-\mathrm{kD}$ form of human urinary CSF-1 (13). A 4.0kb transcript was detected in 10 cases (strong hybridizing signal in 6 cases, less intense signal in 4 cases, $48 \mathrm{~h}$ exposure) (Fig. 1). The smaller CSF-1 transcripts previously detected in phorbol ester-stimulated pancreatic carcinoma cells were not observed (10). RNA from 15 of these 17 cases was separately analyzed for the presence of $c$-fms transcripts (Fig. 2). Seven cases had detectable hybridization with short ( $16 \mathrm{~h}$ ) film exposures, but there was considerable heterogeneity in the $c$-fms signal. Overall, two cases had strongly hybridizing bands of $c$-fms, and five cases had readily detectable, but less intense,

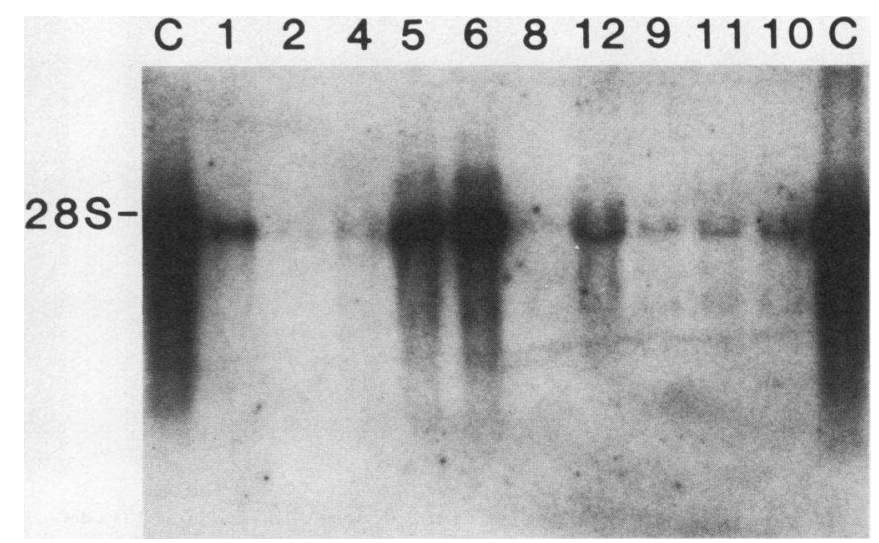

Figure 2. Expression of $c$-fms transcripts by AML cells. c-fms RNA was detected with the pSM3 plasmid containing the 1.0-kb PstI fragment of $v$-fms. 
hybridizing signals. One additional case (case 4) had a very weak signal of uncertain significance which is called negative in the analysis below (Fig. 2 shows results from 10 cases). Of the seven cases expressing $c$-fms, five cases also expressed CSF-1 transcripts. Two cases were $c$-fms positive, CSF-1 negative, and three cases were CSF-1 positive, $c-f m s$ negative. The control lanes in Fig. 2 show RNA from gamma-interferonstimulated normal blood monocytes $(1,000 \mathrm{U} / \mathrm{ml}, 18 \mathrm{~h})$. As previously shown, unstimulated normal monocytes do not express detectable CSF-1 mRNA (12).

To determine the fraction of cells in individual cases of AML that express these genes, in situ hybridization was per- formed in six cases. Smears were made from leukemic blasts depleted of $\mathrm{T}$ cells and monocytes. Biotinylated probes were hybridized to the cells and detected with streptavidin conjugated to alkaline phosphatase using nitroblue tetrazolium as a substrate. In the case shown in Fig. 3 (case 5), $43.9 \pm 3.8 \%$ of total cells had detectable staining for $c$-fms mRNA, while $81.5 \pm 5.5 \%$ of total cells had detectable CSF-1 transcripts. In contrast, no hybridization was observed in RNase-treated cells or in cells hybridized to vector (pBR322) only (Fig. 3). Thus, it is likely in this case that a substantial proportion of leukemic cells coexpressed CSF-1 and c-fms transcripts in the same cell.

Similar in situ hybridization studies were performed on
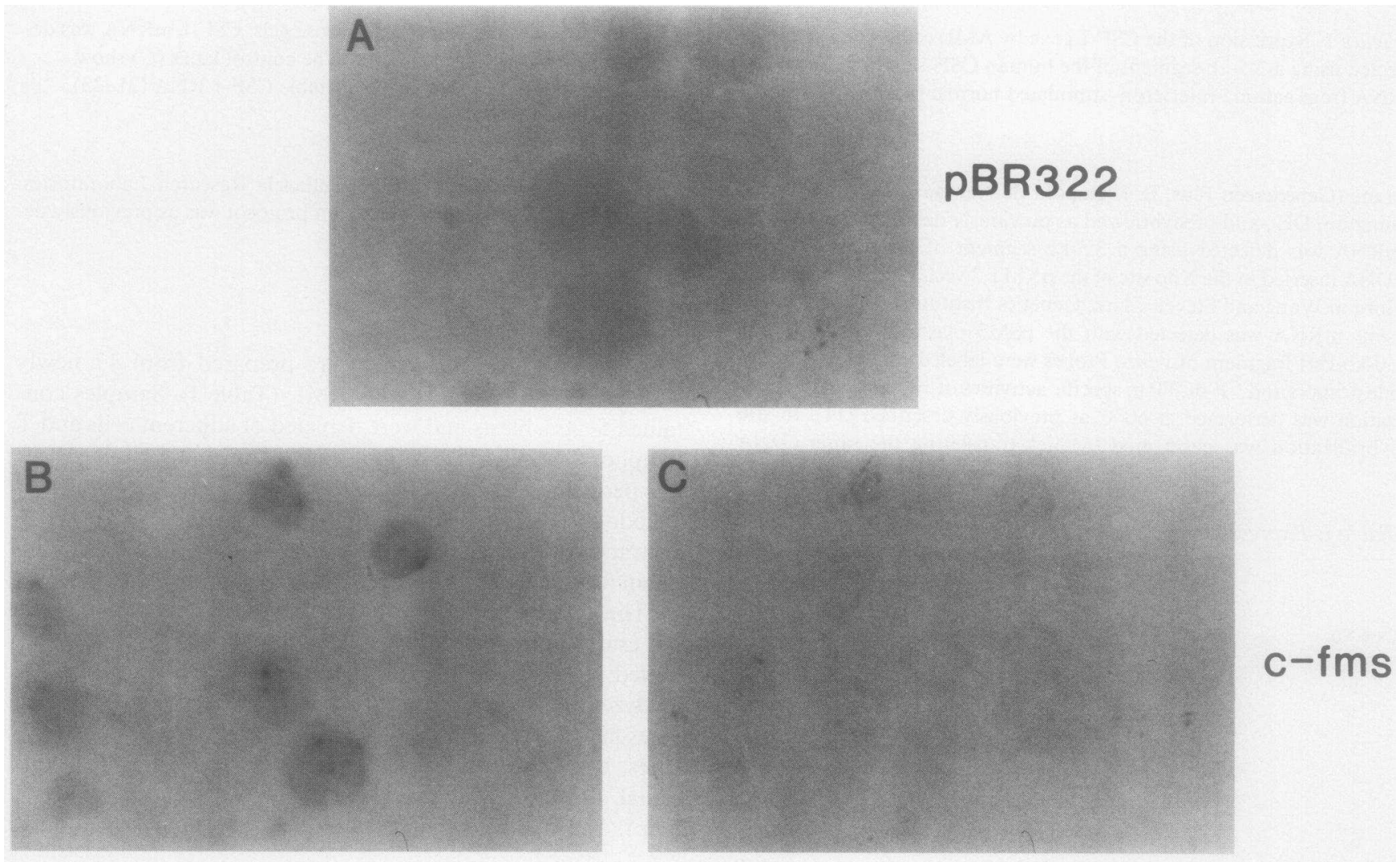

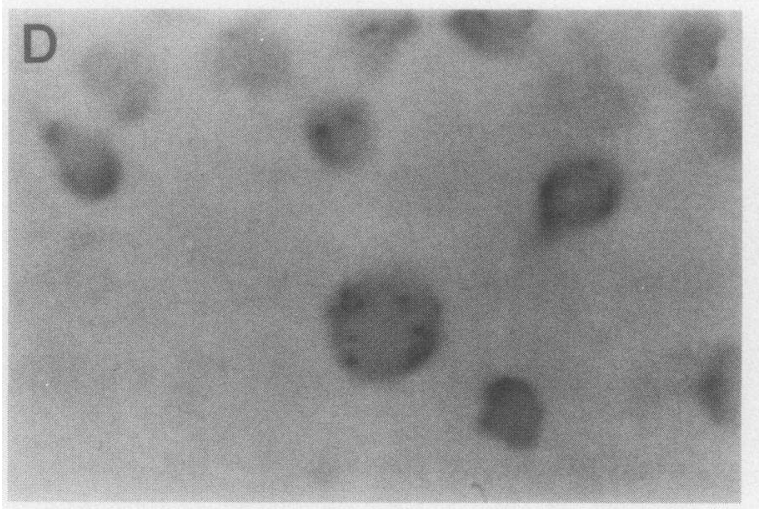

Figure 3. In situ mRNA hybridization of leukemic blasts from case 5. The pSM3 plasmid containing the 1.0-kb PstI fragment of the $v$-fms gene, the pc CSF-12 plasmid containing the 1.6-kb fragment of a human CSF-1 cDNA and pBR322 without insert were nick-translated using biotinylated dUTP. Smears of leukemic myeloblasts were

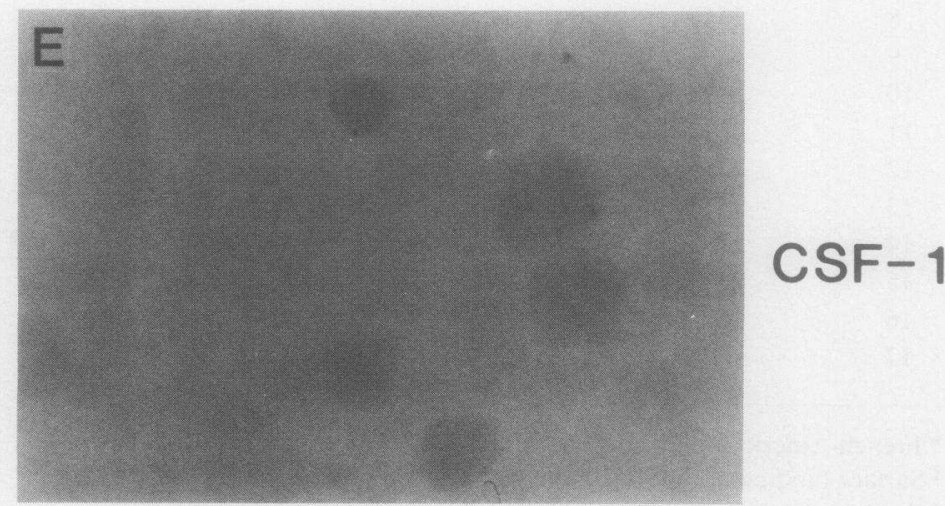

hybridized according to a previously described technique (12). $(A)$ pBR322 hybridization. ( $B$ and $C$ ) $c$-f $f m s$ hybridizations. ( $D$ and $E$ ) CSF-1 hybridizations. The cells in $C$ and $E$ were treated with RNAse before performing the annealing reaction. 
other preparations of leukemic blasts. For example, clearly detectable staining of blasts from case 9 was obtained with the biotinylated CSF-1 probe, while $c$-fms transcripts were barely detectable in these cells (Fig. 4). A low level of $c$-fms RNA was similarly detected by Northern analysis of blasts from case 9 (Fig. 2). The findings by in situ hybridization also corresponded with those obtained by Northern blotting for cases 6 and 8 (Fig. 4). Thus, $c$-fms, but not CSF-1, RNA was detectable in blasts from case 6. Moreover, neither $c$-fms nor CSF-1 transcripts were detectable in blasts from case 8 . These findings further supported the specificity of the in situ hybridizations and demonstrated that, when detectable, $c$-fms and CSF-1 expression occurs in the majority of blasts from an individual patient.
Two assays were used to detect secreted CSF-1 in medium conditioned by leukemic blasts for $48 \mathrm{~h}$ (Table II). Human CSF-1 has been shown to stimulate growth of murine macrophage colonies in agar (10). AML-conditioned media stimulated growth of murine macrophage colonies in none of 14 cases tested. Using an RIA (10), CSF-1 levels were $<20 \mathrm{U} / \mathrm{ml}$ in each of 11 cases tested. This finding is similar to previous observations made on the MIA-PaCa cell line, a pancreatic carcinoma cell line that constitutively expresses the CSF-1 gene, contains intracellular CSF-1 when grown in serum-free medium, but secretes CSF-1 only after treatment with phorbol myristic acid (PMA) (10). We therefore investigated the effects of PMA on CSF-1 release. Of six cases tested, four expressed CSF-1 transcripts before PMA treatment (cases 2, 10, 12, 13)

\section{CSF-1}
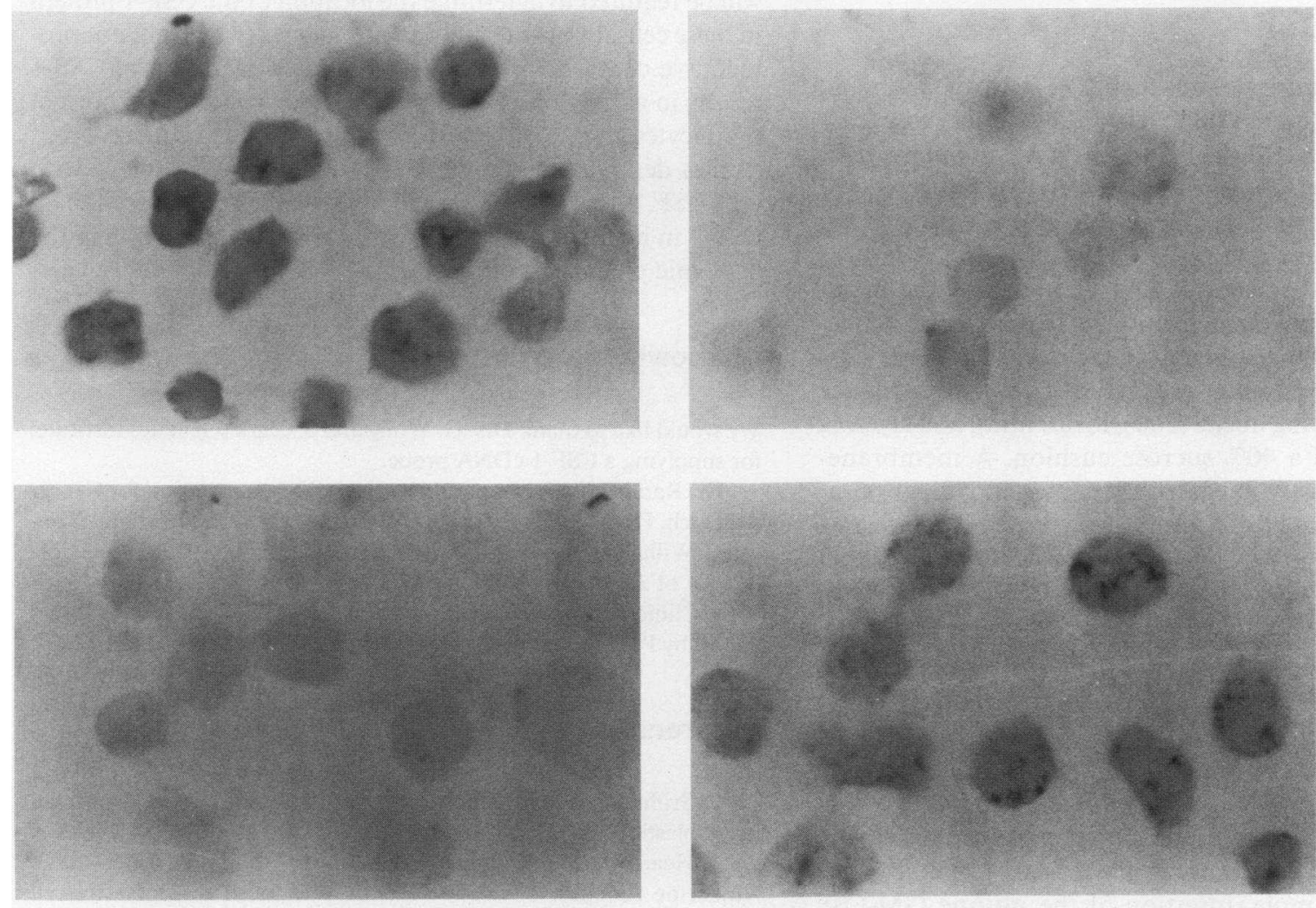

Case 6

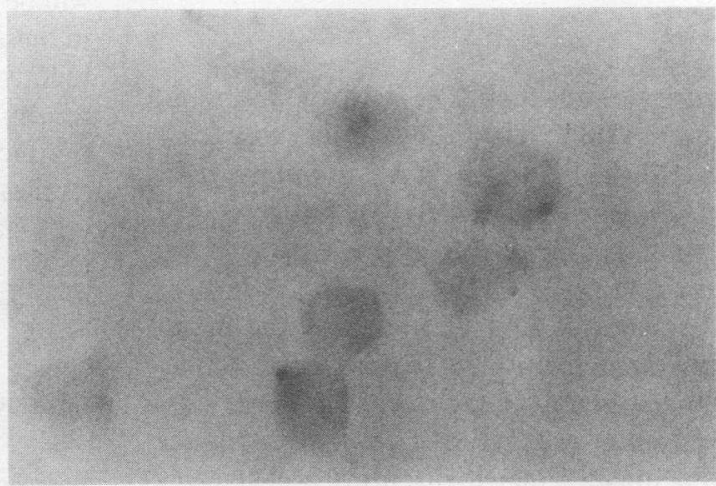

Case 9
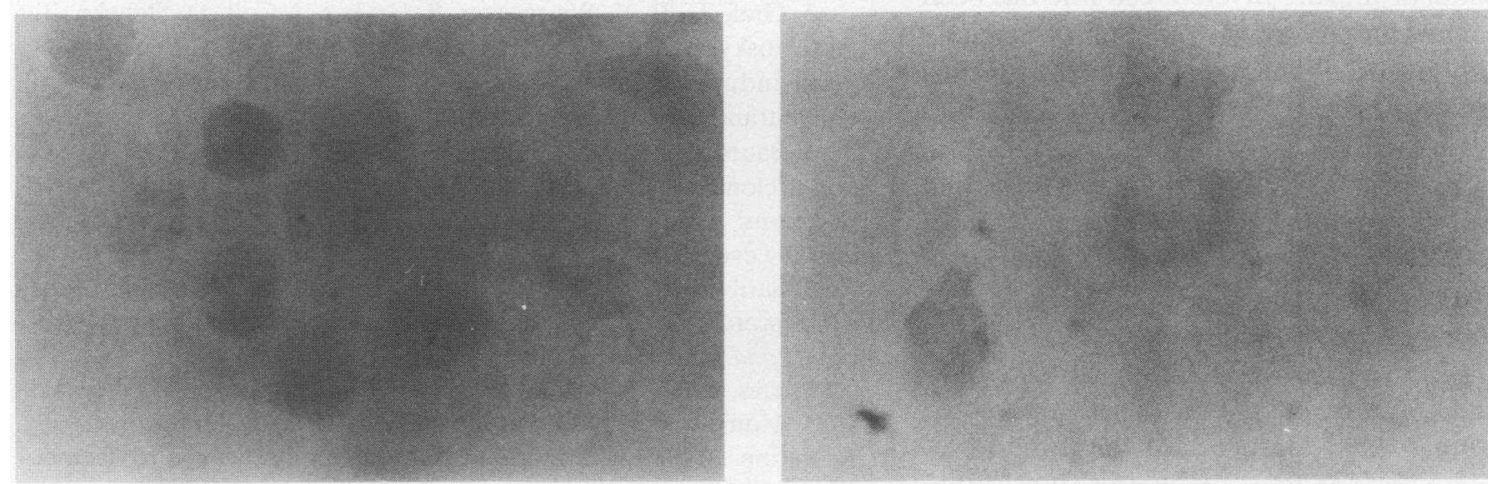

Case 8

Figure 4. In situ mRNA hybridization of leukemic blasts from cases 9,6 , and 8 . Smears of leukemic blasts were hybridized to the biotinylated $c$-fms and CSF-1 probes as described in the legend to Fig. 3. 
Table II. Secretion of CSF-1 by AML Cells

\begin{tabular}{|c|c|c|c|c|}
\hline \multirow[b]{2}{*}{ Case No. } & \multicolumn{2}{|c|}{$\left(\right.$ Colonies $/ 5 \times 10^{4}$ cells $)$} & \multicolumn{2}{|c|}{ CSF-1 } \\
\hline & -PMA & +PMA & -PMA & +PMA \\
\hline & \multicolumn{2}{|c|}{ mean $\pm S E$} & \multicolumn{2}{|c|}{$U / m l$} \\
\hline 2 & 0 & $65 \pm 8$ & 20 & 543 \\
\hline 10 & 0 & $125 \pm 5.7$ & 20 & 520 \\
\hline 11 & 0 & $35 \pm 2.8$ & 20 & 111 \\
\hline 12 & 0 & $32 \pm 2.1$ & 20 & 116 \\
\hline 13 & 0 & 0 & 20 & 20 \\
\hline 14 & 0 & 0 & $\mathrm{NT}^{\ddagger}$ & NT \\
\hline
\end{tabular}

* Two assays were used to detect CSF-1, formation of murine macrophage colonies in agar and RIA. Nonadherent AML cells were cultured in RPMI $1640\left(1 \times 10^{6}\right.$ cells $\left./ \mathrm{ml}\right)$ containing $10 \%$ FBS for $48 \mathrm{~h}$. Medium was harvested and assayed for CSF-1 activity.

${ }^{\ddagger}$ NT, not tested.

and three of these four cases released CSF-1 by bioassay and RIA after PMA treatment (Table II). One additional case (case 11) also secreted detectable CSF-1 after PMA, but did not have detectable CSF-1 transcripts without PMA. The last case (case 14) neither had detectable CSF-1 transcripts nor secreted CSF-1 after PMA treatment.

To identify cell-associated CSF-1 activity, a crude membrane fraction was prepared from cells from case 15 as described (14) by swelling washed, nonadherent leukemic cells (>95\% blasts) in hypotonic buffer, lysing cells in a Dounce homogenizer, removing nuclei ( $200 \mathrm{~g}$ for $10 \mathrm{~min}$ ), and layering the supernatant on a $40 \%$ sucrose cushion. A membraneenriched fraction was then separated by centrifugation at $100,000 \mathrm{~g}$ for $60 \mathrm{~min}$ at $4^{\circ} \mathrm{C}$, rewashed, suspended in $9 \mathrm{mM}$ CHAPS detergent (Pierce Chemical Co., Rockford, IL) for 30 min, then dialyzed against PBS for $3 \mathrm{~d}$. CSF-1 activity was determined by RIA and was $>240 \mathrm{U} / 10^{8}$ cell equivalents. These data suggest that the leukemic cells produce a cell-associated CSF-1 protein.

\section{Discussion}

There is growing evidence to suggest that expression of growth factor genes in certain types of neoplasms may promote transformation. For example, insertion of the murine GM-CSF gene in a factor-dependent murine myeloid cell line has been shown to result in autonomous growth and tumorigenicity (15). Similarly, superinfection of $v-m y b$ or $v$-myc-transformed chicken myeloid cells with retroviruses carrying oncogenes of the $s r c$ gene family induces the cells to release a CSF that supports autocrine growth (3). The recent studies of Sherr and colleagues are particularly relevant $(16,17)$. Introduction of the $v$-fms gene into SV40-immortalized CSF-1-dependent macrophages renders them independent of CSF-1 for growth, and tumorigenic in nude mice (16). Introduction of $v$-fms, but not the human $c$-fms gene, into NIH 3T3 fibroblasts allows for growth in soft agar (17). However, cotransfection of the human $c$-fms and human CSF-1 genes into the same fibroblasts results in agar growth (17). Presumably this transformation is partly or completely due to constitutive activation of the $c$-fms-associated tyrosine kinase by endogenously pro- duced CSF-1. The coexpression of CSF-1 and CSF-1 receptor genes in the cases described here is likely to also confer the phenotype of constitutively activated $c-f m s$ tyrosine kinase.

Despite the finding of CSF-1 transcripts in leukemic cells, secretion of CSF-1 protein was not observed unless the cells were stimulated by PMA. Similar results have, been reported for the pancreatic carcinoma cell line MIA PaCa grown in serum-free medium (10). It is possible, however, that the cells secreted CSF-1 below the limit of detection of the two different assay systems employed here. Alternatively, secreted CSF-1 could be rapidly bound to cell surface receptors and degraded (18). In one case expressing CSF-1 mRNA in which sufficient cells were available, AML cells were lysed and a membraneenriched fraction was shown to contain CSF-1 by immunoassay. It is possible that CSF-1 exists as a membrane protein on these cells. Membrane CSF-1 has been demonstrated in NIH $3 \mathrm{~T} 3$ cells transformed by cotransfection of the human CSF-1 and $c$-fms genes (19). However, further studies of AML cells will be required to determine the location of the CSF-1 protein in these cells. In normal human monocytes (which are nonproliferative cells), $c-f m s$ is expressed and the addition of CSF-1 results in activation of macrophage functions (20). In normal monocytes, the CSF-1 gene is usually not expressed, but recent studies demonstrate the gene is inducible by treatment with GM-CSF, gamma-IFN, or PMA (21-23). The expression of CSF-1 in highly proliferative AML cells may play a role in the leukemic phenotype of these cells.

\section{Acknowledgments}

We would like to thank Drs. G. Wong and S. Clark (Genetics Institute) for supplying a CSF-1 CDNA probe.

Dr. Rambaldi was supported by the Italian Association for Cancer Research, Dr. Vellenga by the Netherlands Cancer Foundation "Koningen Wilhelmina Fonds." Dr. Griffin is a Scholar of the Leukemia Society of America and Dr. Kufe is a recipient of a Burroughs Wellcome Clinical Pharmacology Scholar Award. This work was supported in part by Public Health Service grants CA19389, CA36167, CA42802.

\section{References}

1. Griffin, J. D., and B. Lowenberg. 1986. Clonogenic cells in acute myeloblastic leukemia. Blood. 68:1185-95.

2. Heard, J. M., S. Fichelson, J. Choppin, and B. Varet. 1983. Autocrine function of murine F-MuLV induced myeloblastic cell lines. Int. J. Cancer. 31:337-44.

3. Graf, T., F. V. Weizaecker, S. Grieser, J. Coll, D. Stehelin, T. Patschinsky, K. Bister, C. Bechade, G. Calothy, and A. Leutz. 1986. $v$-mil induces autocrine growth and enhanced tumorigenicity in v-myc-transformed avian macrophages. Cell. 45:357-64.

4. Baumbach, W. R., E. R. Stanley, and M. D. Cole. 1987. Induction of clonal monocyte-macrophage tumors in vivo by a mouse c-myc retrovirus: rearrangement of the CSF-1 gene as a secondary transforming event. Mol. Cell. Biol. 7:664-71.

5. Sariban, E., T. Mitchell, and D. Kufe. 1985. Expression of the c-fms proto-oncogene during human monocytic differentiation. $\mathrm{Na}$ ture (Lond.). 316:64-66.

6. Das, S. K., E. R. Stanley, L. J. Guilbert, and L. W. Forman. 1981. Human colony-stimulating factor (CSF-1) radioimmunoassay: resolution of three subclasses of human colony-stimulating factors. Blood. 58:630-641.

7. Sherr, C. J., C. W. Rettenmier, R. Sacca, M. F. Roussel, A. T. Look, and E. R. Stanley. 1985. The $c$-fms proto-oncogene product is 
related to the receptor for the mononuclear phagocyte growth factor, CSF-1. Cell. 41:665-676.

8. Bennett, J. M., D. Catovsky, M.-T. Daniel, G. Flandrin, D. A. G. Galton, H. Gralnick, and C. Sultan. 1985. Proposed revised criteria for the classification of acute myeloid leukemia. A report of the FrenchAmerican-British Cooperative Group. Ann. Intern. Med. 103:620625 .

9. Griffin, J. D., J. Ritz, L. M. Nadler, and S. F. Schlossman. 1981. Expression of myeloid differentiation antigens on normal and malignant myeloid cells. J. Clin. Invest. 68:932-941.

10. Ralph, P., M. K. Warren, M. T. Lee, J. Csejtey, J. F. Weaver, H. E. Broxmeyer, D. E. Williams, E. R. Stanley, and E. S. Kawasaki. 1986. Inducible production of human macrophage growth factor, CSF-1. Blood. 68:633-639.

11. Young, D. C., K. Wagner, and J. D. Griffin. 1987. Constitutive expression of the granulocyte-macrophage colony-stimulating factor gene in acute myeloblastic leukemia. J. Clin. Invest. 79:100-106.

12. Wakamiya, N., J. Horiguchi, and D. Kufe. 1987. Detection of c-fms and CSF-1 RNA by in situ hybridization. Leukemia. 1:518-520.

13. Wong, G. G., P. A. Temple, A. C. Leary, J. S. Witek-Giannoti, Y. Yang, A. B. Ciarletta, M. Chung, P. Murtha, R. Kriz, R. J. Kaufman, C. R. Ferenz, B. S. Sibley, K. J. Turner, R. M. Hewick, S. C. Clark, N. Yanai, H. Yokota, M. Yamada, M. Saito, K. Motoyoshi, and F. Takaku. 1987. Human CSF-1: molecular cloning and expression of 4-kb cDNA encoding the human urinary protein. Science (Wash. DC). 235:1504-1508.

14. Matsushima, K., M. Taguchi, E. J. Kovacs, H. A. Young, and J. J. Oppenheim. 1986. Intracellular localization of human monocyte associated interleukin-1 (IL-1) activity and release of biologically active IL-1 from monocytes by trypsin and plasmin. J. Immunol. 136:2883-2891.

15. Lang, R. A., D. Metcalf, N. M. Gough, A. R. Dunn, and T. J. Gonda. 1985. Expression of a hemopoietic growth factor cDNA in a factor-dependent cell line results in autonomous growth and tumorigenicity. Cell. 43:531-542.

16. Wheeler, E. F., C. W. Rettenmier, A. T. Look, and C. J. Sherr. 1986. The $v$-fms oncogene induces factor independence and tumorigenicity in CSF-1 dependent macrophage cell line. Nature (Lond.). 324:377-380.

17. Roussel, M. F., T. J. Dull, C. W. Rettenmier, P. Ralph, A. Ullrich, and C. J. Sherr. 1987. Transforming potential of the c-fms proto-oncogene (CSF-1 receptor). Nature (Lond.). 325:549-552.

18. Tuchinski, R. J., I. T. Oliver, L. J. Guilbert, P. W. Tynan, J. R. Warner, and E. R. Stanley. 1982. Survival of mononuclear phagocytes depends on a lineage-specific growth factor that the differentiated cells selectively destroy. Cell. 28:71.

19. Rettenmier, C. W., M. F. Roussel, R. A. Ashmun, P. Ralph, K. Price, and C. J. Sherr. 1987. Synthesis of membrane-bound colony stimulating factor 1 (CSF-1) and downmodulation of CSF-1 receptors in NIH 3T3 cells transformed by cotransfection of the human CSF-1 and c-fms (CSF-1 receptor) genes. Mol. Cell. Biol. 7:2378-87.

20. Warren, M. K., and S. M. Vogel. 1985. Bone-marrow-derived macrophages: development and regulation of differentiation markers by colony-stimulating factor and interferons. J. Immunol. 134:982989.

21. Horiguchi, J., M. K. Warren, P. Ralph, and D. Kufe. 1986. Expression of the macrophage specific colony-stimulating factor (CSF-1) during human monocyte differentiation. Biochem. Biophys. Res. Commun. 141:924-930.

22. Horiguchi, J., M. K. Warren, and D. Kufe. 1987. Expression of the macrophage-specific colony-stimulating factor in human monocytes treated with granulocyte-macrophage colony-stimulating factor. Blood. 69:1259-1261.

23. Rambaldi, A., D. C. Young, and J. D. Griffin. 1987. Expression of the M-CSF (CSF-1) gene by human monocytes. Blood. 69:14091413. 